
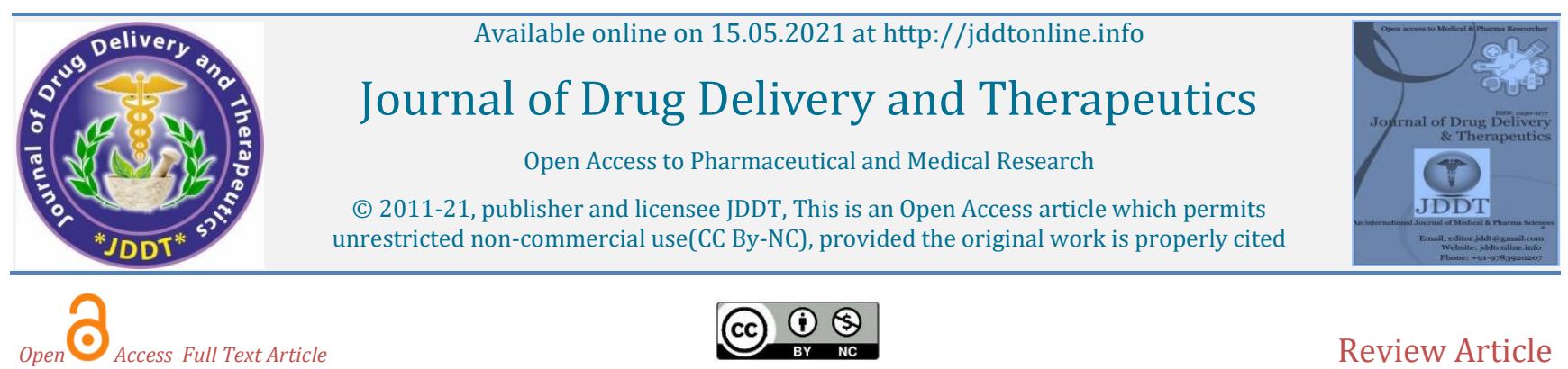

Review Article

\title{
Literature Review: Risk Factors Affecting Hearing Loss among Fishermen in Indonesia
}

\author{
Meirina Ernawati \\ Lecture Dept. of Occupational Safety and Health, Faculty of Public Health, Airlangga University, Indonesia
}

\section{Article Info:

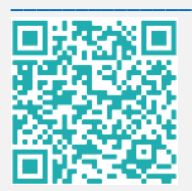 \\ Article History: \\ Received 21 March 2021; \\ Review Completed 28 April 2021 \\ Accepted 04 May 2021; \\ Available online 15 May 2021 \\ Cite this article as: \\ Ernawati M, Literature Review: Risk Factors Affecting Hearing Loss among Fishermen in Indonesia, Journal of Drug Delivery and Therapeutics. 2021; 11(3):153-159 DOI: http://dx.doi.org/10.22270/jddt.v11i3.4780 \\ *Address for Correspondence: \\ Meirina Ernawati Lecturer, Dept. of Occupational Safety and Health, Faculty of Public Health, Airlangga \\ University, Indonesia}

\begin{abstract}
Indonesia is a country where most of the people work as fishermen because most of its territory is water. Fishermen are a profession that has a high risk of occupational disease in the form of hearing loss which causes losses in the form of permanent disabilities, decreased financial income and quality of life, as well as the mental health of fishermen. The purpose of this study was to identify the risk factors that cause occupational hearing loss experienced by fishermen. This research is a literature review conducted using the Google Scholar database with the keywords "Hearing Loss", "Occupational Diseases", "Fishermen", and "Indonesia". The results of this literature review show that diving and non-diver fishermen have a risk of hearing loss due to personal factors such as age, years of service, knowledge, attitudes, and behavior, while occupational factors that influence are noise intensity, length of exposure to availability of ear protection equipment, length of time, and depth of diving activity.
\end{abstract}

Keywords: hearing loss, occupational diseases, fishermen

\section{INTRODUCTION}

Indonesia is one of the largest archipelagic and maritime countries in the world with a sea area of 3.25 million $\mathrm{km} 2$ and an exclusive economic zone of 2.55 million $\mathrm{km} 2$ or about $75 \%$ of the country's total area. ${ }^{1}$. Based on this, the fisheries sector has become one of the largest livelihoods in Indonesia, as evidenced in 2016 there were 965,756 households and fisheries companies scattered throughout Indonesia ${ }^{2}$ and in 2018 the number of people who work as fishermen is $1,685,018$ people 3 .

According to the ILO, every year there are 160 million workers in the formal and informal sectors who experience diseases due to the work environment around the world 4 . The fishing profession is an informal sector job that is included in the high-risk category so that many fishermen suffer from occupational diseases ${ }^{5}$ which is caused due to exposure to hazards originating from work, work tools, materials, processes and the work environment ${ }^{6}$. The large number of fishermen groups experiencing occupational diseases is due to the weak application of occupational safety and health aspects which aim to guarantee and protect workers from occupational accidents and diseases 7.

Research conducted on fishermen on the Gulf Coast, United States showed that out of 117 respondents there were $30.5 \%$ of fishermen with mild hearing loss, $18.8 \%$ moderate hearing loss, $8.1 \%$ moderate-severe hearing loss, $1.5 \%$ severe hearing loss, and $0.5 \%$ hearing loss very heavy ${ }^{8}$. Losses caused by the occurrence of hearing loss experienced by ISSN: 2250-1177 fishermen due to work, namely that almost all hearing loss is felt to be permanent so that it can interfere with fishermen's work activities and have an impact on decreasing financial income so that it can also cause a decrease in the quality of life of fishermen which has an impact on the emergence of health problems. other. Hearing loss due to work has been shown to affect mental health due to stress due to the inability to communicate with other people ${ }^{9}$. Based on this background, the aims of this literature review is to identify risk factors that cause occupational hearing loss experienced by fishermen.

\section{METHODOLOGY}

This literature review study was conducted to explore the risk factors that influence the incidence of occupational hearing loss experienced by fishermen. A literature search was carried out in April 2021 using a database source, namely Google Scholar. Literature search was carried out using keywords which became the main topic term, namely hearing loss "AND" occupational disease "AND" fishermen "AND" Indonesia. Researchers set limits in the search for related literature used as data, namely journals published in 2016-2021 to obtain valid and out-of-date information.

The inclusion criteria included in the selection of this literature review study were journals related to the incidence of occupational hearing loss experienced by fishermen in Indonesia, journal texts in Indonesian or English Danger. The exclusion criteria included in the selection of this literature review study were literature 
review articles. The variables in this study are risk factors that affect the incidence of occupational hearing loss experienced by fishermen.

\section{DATA EXTRACTION}

Journals were selected by researchers independently through the Google Scholar database which were searched using the keywords "Hearing Loss, Occupational Diseases, Fishermen, Indonesia" and "Hearing Loss, Occupational Disease, Fishermen, Indonesia". During data synthesis, 937 articles were obtained via Google Scholar. 349 articles were released after scanning based on the restrictions on the year the articles were published, namely 2016-2021. 466 articles were removed by reviewing the title and 70 articles were removed by reviewing the abstract. 30 articles were found relevant because they discussed occupational hearing loss experienced by fishermen in Indonesia. During the full text analysis, out of 30 articles, another 18 articles were excluded because they did not fit the inclusion criteria. This systematic literature review finally selected 12 articles that were relevant and fit the study inclusion criteria.

Figure 1 describes the process of selecting articles according to the guidelines from the Preferred Reporting Literature Reviews and Meta-analysis (PRISMA). The initial search returned a total of 937 articles showing high relevance to the topic under review. After duplicating articles and filtering published years, titles and abstracts, 30 articles entered the next stage, namely full text review and eligibility based on inclusion and exclusion criteria determined by the researcher. The 12 research articles that met the requirements were then reviewed for quality and synthesized in this final literature review report.

Figure 1 PRISM Flowchart for Literature Review

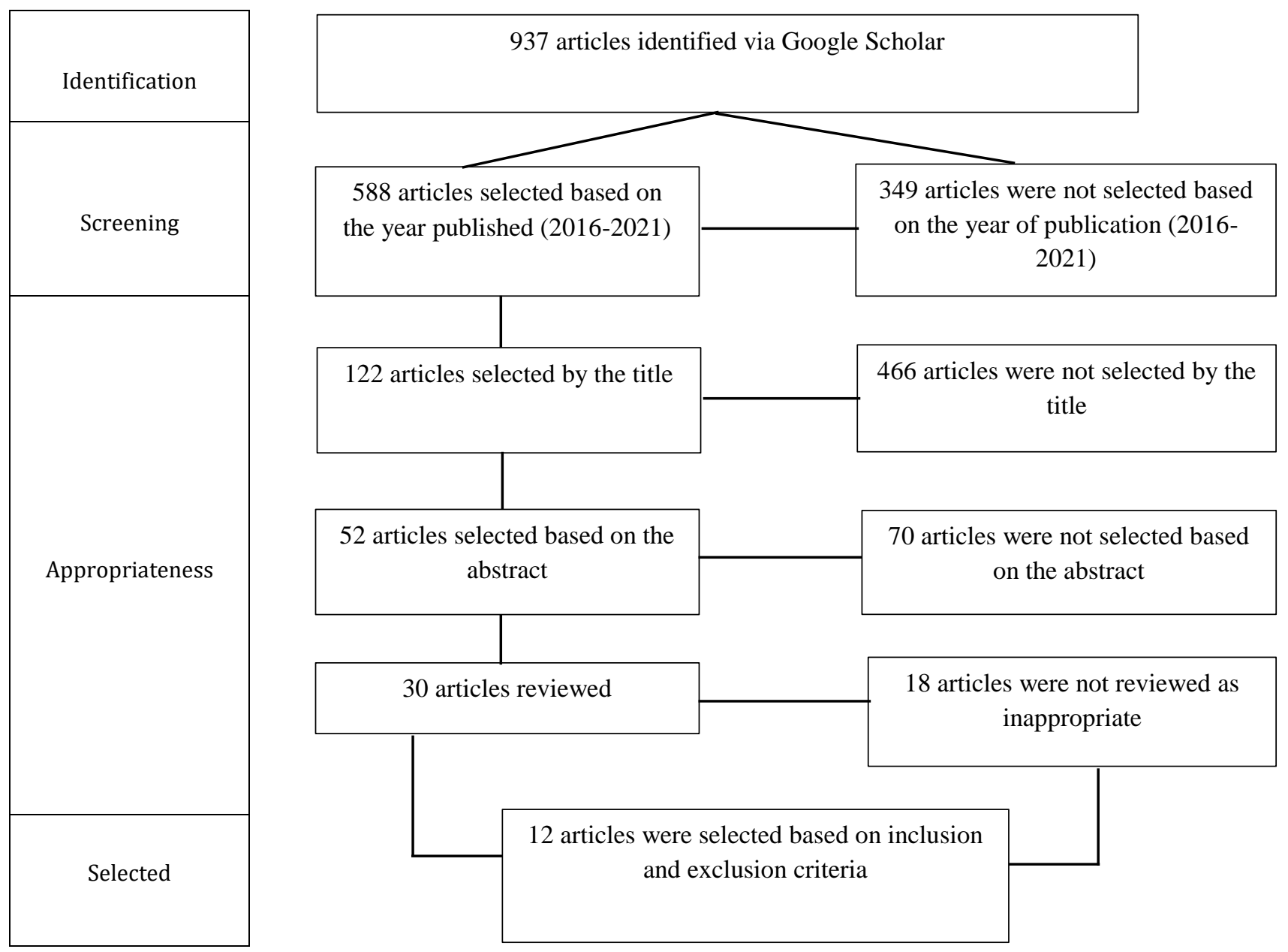

\section{RESULTS}

The results of this review literature is indicate that the profession of fishermen in Indonesia is divided into two, namely fishermen who fish with and without diving. Both groups of the fishing profession have a risk of experiencing the same occupational disease, one of which is hearing loss in the form of a decreased hearing threshold. $97.50 \%$ of fishermen experienced hearing loss with several levels of severity, namely $52.50 \%$ mild level, $43.75 \%$ moderate level and $1.25 \%$ high severity level 10 . The hearing loss experienced by fishermen is caused by several factors. Risk factors that can cause fishermen to experience hearing loss can come from personal factors and work factors..

Personal factors that come from within fishermen who are at risk of causing hearing loss based on research conducted on fishermen who use motorized boats in Barombong village and fishermen in Palopo city, namely age and years of work 11,10. Other research conducted on traditional diving fishermen shows that personal factors that affect hearing loss in the form of a decrease in threshold are fishermen's knowledge of the causes and symptoms of barotrauma and 


\section{Ernawati et al}

diving methods as well as fishermen's attitudes regarding occupational safety and health aspects. $12,13.39 .5 \%$ of the 15 respondents of traditional diving fishermen in Ambon City who experience hearing loss in the form of a decrease in hearing threshold are due to poor occupational safety and health behavior during diving activities such as not doing equalization techniques while diving 20,14 .

Job factors that are at risk of causing hearing loss are noise from ship engines and compressor engines, which generally have a noise intensity of $>85$ dBA. 15,11,10,16. High noise intensity when combined with long exposure time, frequency and long exposure period will increase the risk and exacerbate the degree of hearing loss in fishermen 17. Another factor related to the occurrence of hearing loss felt
Journal of Drug Delivery \& Therapeutics. 2021; 11(3):153-59

by fishermen due to noise exposure is the unavailability of ear protection in the form of earplugs ${ }^{15}$. To get a more diverse catch of marine products, most fishermen do diving activities in the sea. Diving activities can increase the risk of hearing loss if done with inappropriate methods. The length of time or duration, frequency and depth of dives can affect hearing loss 18,19,20.

\section{TABLE OF THE REVIEWED ARTICLES}

After the researcher selects and extracts the data for each article obtained, a detailed description of the name of the researcher, title, research design, respondents, research strengths and results, and research limitations are summarized in Table 1.

Table 1: Research on the Risk Factors for Occupational Hearing Loss in Fishermen in Indonesia

\begin{tabular}{|c|c|c|c|c|c|c|}
\hline No & Title & Authors & Objective & Methods & $\begin{array}{l}\text { Location and } \\
\text { Sample }\end{array}$ & Results \\
\hline 1 & $\begin{array}{l}\text { Audiometric } \\
\text { Profile of } \\
\text { Fishermen using } \\
\text { Motor Boat in } \\
\text { Barombong } \\
\text { Village, Makassar }\end{array}$ & $\begin{array}{l}\text { Anwar, Savitri } \\
\text { dan Dyah, } 2019\end{array}$ & $\begin{array}{l}\text { Provides an } \\
\text { overview of the } \\
\text { factors causing the } \\
\text { prevalence and } \\
\text { degree of hearing } \\
\text { loss in fishermen in } \\
\text { Barombong village, } \\
\text { Makassar }\end{array}$ & Cross sectional & $\begin{array}{l}\text { Barombong } \\
\text { Village, } \\
\text { Massar. } \\
40 \text { fishermen }\end{array}$ & $\begin{array}{l}\text { A significant } \\
\text { decrease in hearing } \\
\text { power is due to } \\
\text { factors of age, years } \\
\text { of service and the } \\
\text { intensity of the noise } \\
\text { from the motor } \\
\text { boats used for } \\
\text { fishing. }\end{array}$ \\
\hline 2 & $\begin{array}{l}\text { Various Factors } \\
\text { That Influence } \\
\text { Middle Ear } \\
\text { Barotrauma on } \\
\text { Traditional } \\
\text { Divers (Study in } \\
\text { the Balaesang } \\
\text { Tanjung Area, } \\
\text { Donggala } \\
\text { Regency) }\end{array}$ & $\begin{array}{l}\text { Martinus, } \\
\text { Hadisaputro } \\
\text { dan Munasik, } \\
2019\end{array}$ & $\begin{array}{l}\text { To determine the } \\
\text { influence of host } \\
\text { and environmental } \\
\text { factors that cause } \\
\text { middle ear } \\
\text { barotarauma }\end{array}$ & Cross sectional & $\begin{array}{l}\text { Balaesang } \\
\text { Tanjung, } \\
\text { Donggala. } \\
78 \text { traditional } \\
\text { diving } \\
\text { fishermen }\end{array}$ & $\begin{array}{l}\text { Dive time } \geq 7 \\
\text { minutes; The } \\
\text { frequency of dives } \geq \\
4 \text { days / week and } \\
\text { never getting health } \\
\text { education is related } \\
\text { to the incidence of } \\
\text { middle ear } \\
\text { barotrauma in } \\
\text { traditional diving } \\
\text { fishermen }\end{array}$ \\
\hline 3 & $\begin{array}{l}\text { Diving Frequency } \\
\text { Increase the Risk } \\
\text { Barotrauma in } \\
\text { Traditional } \\
\text { Fisherman-Divers }\end{array}$ & $\begin{array}{l}\text { Fatimah, } \\
\text { Andarini dan } \\
\text { Astari, } 2019\end{array}$ & $\begin{array}{l}\text { Identify the } \\
\text { correlation } \\
\text { between the } \\
\text { frequency of diving } \\
\text { and dive rest time } \\
\text { with the incidence } \\
\text { of barotrauma }\end{array}$ & Case control & $\begin{array}{l}\text { Tasipi Island. } \\
174 \text { traditional } \\
\text { diving } \\
\text { fishermen }\end{array}$ & $\begin{array}{l}\text { There is a significant } \\
\text { relationship } \\
\text { between the } \\
\text { frequency of diving } \\
\text { and the incidence of } \\
\text { barotrauma (p value } \\
\text { - 0.000), that is, } \\
\text { fishermen who dive } \\
\text { twice a day have a } \\
5.48 \text { times higher } \\
\text { risk of experiencing } \\
\text { barotrauma (OR = } \\
5.48 \text { ), while the } \\
\text { resting time while } \\
\text { diving has no } \\
\text { relationship with the } \\
\text { incidence of } \\
\text { barotrauma ear }\end{array}$ \\
\hline 4 & $\begin{array}{l}\text { Risk Factors of } \\
\text { Ear Barotrauma } \\
\text { for Fishermen } \\
\text { Divers in Watu } \\
\text { Ulo Hamlet, } \\
\text { Sumberejo } \\
\text { Village, Ambulu } \\
\text { District, Jember } \\
\text { Regency }\end{array}$ & $\begin{array}{l}\text { Navisah, } \\
\text { Ma'rufi dan } \\
\text { Sujoso, } 2016\end{array}$ & $\begin{array}{l}\text { Identify the risk } \\
\text { factors associated } \\
\text { with the incidence } \\
\text { of barotrauma }\end{array}$ & Cross sectional & $\begin{array}{l}\text { Watu Ulo } \\
\text { Hamlet, } \\
\text { Sumberejo } \\
\text { Village, } \\
\text { Ambulu } \\
\text { District, } \\
\text { Jember } \\
\text { Regency. } \\
34 \text { traditional } \\
\text { diving }\end{array}$ & $\begin{array}{l}\text { There is a significant } \\
\text { relationship } \\
\text { between depth and } \\
\text { duration or duration } \\
\text { of diving with the } \\
\text { incidence of ear } \\
\text { barotrauma, while } \\
\text { other variables such } \\
\text { as age, years of } \\
\text { service, frequency of }\end{array}$ \\
\hline
\end{tabular}




\begin{tabular}{|c|c|c|c|c|c|c|}
\hline & & & & & fishermen & $\begin{array}{l}\text { diving and resting } \\
\text { time do not have a } \\
\text { significant } \\
\text { relationship. }\end{array}$ \\
\hline 5 & $\begin{array}{l}\text { Safety Factors } \\
\text { Affecting the } \\
\text { Health Status of } \\
\text { Traditional } \\
\text { Fisherman in the } \\
\text { Coastal Area } \\
\text { Surabaya }\end{array}$ & $\begin{array}{l}\text { Arini et al., } \\
2020\end{array}$ & $\begin{array}{l}\text { Analyze safety } \\
\text { factors related to } \\
\text { the health status of } \\
\text { traditional } \\
\text { fishermen }\end{array}$ & Cross sectional & $\begin{array}{l}\text { Surabaya. } \\
35 \text { traditional } \\
\text { diving } \\
\text { fishermen }\end{array}$ & $\begin{array}{l}\text { There is a significant } \\
\text { relationship } \\
\text { between the } \\
\text { equalization } \\
\text { technique and the } \\
\text { incidence of } \\
\text { barotrauma } \\
\text { experienced by } \\
\text { traditional diving } \\
\text { fishermen. }\end{array}$ \\
\hline 6 & $\begin{array}{l}\text { The Correlation } \\
\text { between } \\
\text { Knowledge and } \\
\text { Hearing Loss Due } \\
\text { to Gathering of } \\
\text { Traditional } \\
\text { Divers on the } \\
\text { Bugis Campus: } \\
\text { Case Report }\end{array}$ & $\begin{array}{l}\text { Rahman, } \\
\text { Kurniawati dan } \\
\text { Apriani, } 2020\end{array}$ & $\begin{array}{l}\text { Identify the } \\
\text { correlation } \\
\text { between } \\
\text { knowledge and } \\
\text { hearing loss in } \\
\text { traditional diving } \\
\text { fishermen }\end{array}$ & Quantitative & $\begin{array}{l}\text { Tanjung } \\
\text { Pinang. } \\
38 \text { traditional } \\
\text { diving } \\
\text { fishermen }\end{array}$ & $\begin{array}{l}\text { There is a } \\
\text { relationship } \\
\text { between knowledge } \\
\text { and the incidence of } \\
\text { hearing loss due to } \\
\text { diving experienced } \\
\text { by traditional diving } \\
\text { fishermen }\end{array}$ \\
\hline 7 & $\begin{array}{l}\text { Analysis of the } \\
\text { Correlation } \\
\text { between Noise } \\
\text { Level and Hearing } \\
\text { Loss in } \\
\text { Fishermen in } \\
\text { Pontap Village, } \\
\text { Palopo City, South } \\
\text { Sulawesi } \\
\text { Province in } 2016\end{array}$ & Tasik, 2018 & $\begin{array}{l}\text { Identify and assess } \\
\text { hearing loss caused } \\
\text { by noise, age, years } \\
\text { of service and } \\
\text { length of work }\end{array}$ & Cross sectional & $\begin{array}{l}\text { South } \\
\text { Sulawesi. } \\
75 \text { fishermen }\end{array}$ & $\begin{array}{l}\text { There is a significant } \\
\text { relationship } \\
\text { between noise } \\
\text { intensity, age, and } \\
\text { years of service with } \\
\text { the incidence of } \\
\text { decreased hearing } \\
\text { threshold or hearing } \\
\text { loss felt by } \\
\text { fishermen }\end{array}$ \\
\hline 8 & $\begin{array}{l}\text { The Correlation } \\
\text { between Noise } \\
\text { and the Use of Ear } \\
\text { Plugs with } \\
\text { Hearing } \\
\text { Disorders on } \\
\text { Fishermen }\end{array}$ & $\begin{array}{l}\text { Sholihah dan } \\
\text { Hanafi, } 2017\end{array}$ & $\begin{array}{l}\text { Knowing the } \\
\text { correlation } \\
\text { between boat } \\
\text { engine noise and } \\
\text { the use of earplugs } \\
\text { on hearing loss in } \\
\text { fishermen }\end{array}$ & Cross sectional & $\begin{array}{l}\text { Laut Utara } \\
\text { Island, South } \\
\text { Kalimantan } \\
186 \text { nelayan }\end{array}$ & $\begin{array}{l}\text { There is a significant } \\
\text { relationship } \\
\text { between noise } \\
\text { intensity that } \\
\text { exceeds the } \\
\text { threshold value> } 85 \\
\text { dBA and the use of } \\
\text { ear protection } \\
\text { equipment in the } \\
\text { form of earplugs } \\
\text { with the incidence of } \\
\text { decreased hearing } \\
\text { threshold } \\
\text { experienced by } \\
\text { fishermen. }\end{array}$ \\
\hline 9 & $\begin{array}{l}\text { Identification of } \\
\text { Occupational } \\
\text { Health and Safety } \\
\text { Hazards in } \\
\text { Fishermen's } \\
\text { Activities }\end{array}$ & Vinezzia, 2021 & $\begin{array}{l}\text { Identify potential } \\
\text { occupational safety } \\
\text { and health hazards } \\
\text { to fishermen }\end{array}$ & $\begin{array}{l}\text { Secondary data } \\
\text { analysis }\end{array}$ & $\begin{array}{l}11 \text { articles, } \\
\text { 1government } \\
\text { book policy, } \\
\text { and } 6 \text { manuals } \\
\text { health }\end{array}$ & $\begin{array}{l}\text { Fishermen are at } \\
\text { risk of hearing loss } \\
\text { caused by noise } \\
\text { coming from boat } \\
\text { engines and } \\
\text { compressor engines } \\
\text { with noise intensity } \\
\text { up to } 99.7 \mathrm{dBA}\end{array}$ \\
\hline 10 & $\begin{array}{l}\text { Factors Related to } \\
\text { Hearing Disorder } \\
\text { on Traditional } \\
\text { Fishermen in } \\
\text { Namrole Sub- } \\
\text { District South } \\
\text { Buru Regency }\end{array}$ & $\begin{array}{l}\text { Sangaji et al., } \\
2020\end{array}$ & $\begin{array}{l}\text { Identifying factors } \\
\text { associated with } \\
\text { hearing loss in } \\
\text { traditional } \\
\text { fishermen }\end{array}$ & $\begin{array}{l}\text { Descriptive } \\
\text { quantitative }\end{array}$ & $\begin{array}{l}\text { Maluku. } \\
35 \text { traditional } \\
\text { diving } \\
\text { fishermen }\end{array}$ & $\begin{array}{l}\text { Diving depth has a } \\
\text { significant } \\
\text { relationship with } \\
\text { hearing loss } \\
\text { experienced by } \\
\text { traditional } \\
\text { fishermen }\end{array}$ \\
\hline 11 & $\begin{array}{l}\text { Safety Behaviour } \\
\text { and Healthy } \\
\text { Diving: A }\end{array}$ & $\begin{array}{l}\text { Kusnanto et al., } \\
2020\end{array}$ & $\begin{array}{l}\text { Describe the } \\
\text { occupational safety } \\
\text { and health }\end{array}$ & Qualitative & $\begin{array}{l}\text { Maluku. } \\
15 \text { traditional }\end{array}$ & $\begin{array}{l}\text { Fishermen who } \\
\text { experience hearing } \\
\text { loss in the form of a }\end{array}$ \\
\hline
\end{tabular}




\begin{tabular}{|c|c|c|c|c|c|c|}
\hline & $\begin{array}{l}\text { Qualitative Study } \\
\text { in the Traditional } \\
\text { Diverse } \\
\text { Fishermen }\end{array}$ & & $\begin{array}{l}\text { behavior of } \\
\text { traditional diving } \\
\text { fishermen in a } \\
\text { factual manner }\end{array}$ & & $\begin{array}{l}\text { diving } \\
\text { fishermen }\end{array}$ & $\begin{array}{l}\text { decrease in hearing } \\
\text { threshold due to } \\
\text { poor occupational } \\
\text { health and safety } \\
\text { behavior, such as the } \\
\text { use of compressors } \\
\text { and failure of } \\
\text { equalization } \\
\text { techniques when } \\
\text { fishermen are diving }\end{array}$ \\
\hline 12 & $\begin{array}{l}\text { The Correlation } \\
\text { between } \\
\text { Knowledge and } \\
\text { Attitude with the } \\
\text { Barotrauma } \\
\text { Incident at the } \\
\text { Kadatua Divers } \\
\text { Without Scuba }\end{array}$ & $\begin{array}{l}\text { Pinto et al., } \\
2020\end{array}$ & $\begin{array}{l}\text { Identify the } \\
\text { relationship } \\
\text { between } \\
\text { knowledge and } \\
\text { attitudes with the } \\
\text { incidence of } \\
\text { barotrauma in non- } \\
\text { scuba diving } \\
\text { fishermen }\end{array}$ & Cross sectional & $\begin{array}{l}\text { Tekonea Raya } \\
\text { Village, } \\
\text { Konawe } \\
\text { Islands } \\
\text { Regency. } \\
36 \text { traditional } \\
\text { diving } \\
\text { fishermen } \\
\text { without scuba }\end{array}$ & $\begin{array}{l}\text { There is a significant } \\
\text { relationship } \\
\text { between knowledge } \\
\text { and attitudes } \\
\text { regarding the } \\
\text { correct diving } \\
\text { method and the } \\
\text { incidence of } \\
\text { barotrauma } \\
\text { experienced by } \\
69.4 \% \text { of } \\
\text { respondents }\end{array}$ \\
\hline
\end{tabular}

\section{DISCUSSION}

Fishermen are informal jobs that aim to catch marine products so that based on the fishing method, the fishing profession is divided into two, namely fishermen who catch fish using the hook or net method, and fishermen who catch fish using the diving method. ${ }^{21}$. The fishing profession has become one of the professions that have high risks related to safety and health, one of which is due to physical hazards, namely noise caused by work activities that can cause hearing loss. ${ }^{22}$. Based on the research results, the risk factors that cause hearing loss in fishermen are divided into personal factors and occupational factors.

Age is one of the risk factors in fishermen which is proven to be related to a history of occupational diseases caused by biological changes exacerbated by exposure to hazards from the workplace 23 . This theory is in accordance with the results of research conducted by Tasik, that $68.18 \%$ of fishermen with hearing loss are more than 40 years old 11 . This statement is reinforced by other research which shows that fishermen who are $<40$ years old do not suffer from work-related hearing loss, while fishermen who are more than 40 years old have moderate to high levels of hearing loss. ${ }^{10}$. There is a relationship between the age of fishermen and hearing loss due to changes in the structure of the cochlea and vestibulocochlear nerves due to atrophy and degeneration of the supporting hair cells in the cortiary organs. ${ }^{24}$. Cochlear degeneration will make it easier to decrease the hearing threshold if exposed to noise, this is evident from the results of the statistical analysis of odds ratio of 2.429 which shows that workers aged $>40$ years have a 2.429 times higher risk of lowering the hearing threshold than workers aged $\leq 40$ years. 25 .

Another factor behind the relationship between age and the incidence of occupational diseases such as hearing loss is that older workers tend to feel more experienced and do not easily accept changes related to improvements in working methods so that they have unsafe work behaviors ${ }^{26}$. As a result, older workers are more at risk of being exposed to hazards in the workplace so that the chances of experiencing work-related illnesses increase.
Another personal factor that can increase the risk of workrelated hearing loss is work mass. Fishermen who have worked for $>10$ years are proven to have hearing loss 11,10 . Based on research conducted on workers exposed to noise, working years> 15 years have a 9.09 times greater risk of experiencing hearing loss 27 . There is a correlation between work tenure and the incidence of hearing loss due to work, because the longer a person's work period is, the longer he is exposed to a hazard from his workplace 28 . Workers who are exposed to noise during the work period of 10 - 15 years will cause the corti hair cells to tear, causing total destruction of the corpus organs, resulting in a permanent increase in the hearing threshold 29.

Fishermen's knowledge of occupational safety and health is another personal factor that can cause work-related hearing loss to be felt by fishermen. This is in accordance with the two results of two studies which prove that $52.78 \%$ of the 36 Kadatua diving fishermen without scuba and $71.07 \%$ of the 38 traditional diving fishermen on the Bugis Campus who experience hearing loss have less knowledge of techniques and the consequences of diving. does not comply with occupational safety and health standards 12,13. Knowledge plays a very important role in shaping a person's behavior. Fishermen with a high level of knowledge related to K3 aspects tend to have the right attitude to address hazards in the work environment 30 , so that fishermen are able to identify the types of hazards that exist in their workplaces and be able to establish control measures to minimize their risk of experiencing occupational diseases. The knowledge that divers fishermen need to have to reduce the risk of hearing loss is about equalization techniques 31 because besides being caused by noise exposure, hearing loss experienced by fishermen can also be caused due to middle ear barotrauma which is caused by inadequate equalization between middle ear space pressure and ambient pressure due to diving too fast at a certain depth ${ }^{32}$. During diving, the middle ear pressure becomes less and less and the Eustachian tube must be open to balance this pressure, for that fishermen need to have knowledge to perform equalization techniques 20,33 . This technique is used to open the Eustachian tubes so that air can enter the ear cavity by blowing air through the closed nose. 


\section{Ernawati et al}

Attitude is the initial response in a person to react to a certain situation before deciding to take an action. The results of statistical analysis carried out on traditional diving fishermen of the Kaudata tribe showed that there was a significant relationship between attitudes and the incidence of hearing loss in the form of barotrauma as evidenced by $\mathrm{p}$ value $=0.011 \quad(<0.05) 12$. This research is further strengthened by the results of other studies conducted by Kalalo, Kaunang and Kawatu which show that fishermen who have poor attitudes about occupational safety and health aspects have a 1,467 times higher risk of experiencing work accidents compared to fishermen who have good attitudes 34. Attitude has a positive and significant relationship with commitment 35 , so that the better the attitude of the fishermen regarding occupational safety and health, the stronger the commitment they have to behave in a safe work. Work behavior is a direct causative factor that can lead to accidents and occupational diseases 36 . This theory is in accordance with the results of research conducted on 15 traditional diving fishermen which showed that fishermen who experienced hearing loss due to diving activities were due to unsafe work behavior related to diving techniques. This is because traditional diving fishermen tend to have weak knowledge and attitudes regarding occupational safety and health aspects, so that the working methods of diving are more influenced by habits acquired from generation to generation ${ }^{14}$. Knowledge and attitudes are the main factors that can influence a person's behavior, so that improvements in knowledge and attitudes will be directly proportional to better behavior change 37 .

Factors from outside the fishermen that can cause hearing loss are the exposure to noise received by fishermen from boat engines and compressors. Noise is unwanted sound that can lead to audiometric and non-audiometric complaints. The intensity of noise in the workplace that exceeds the threshold value will result in audiometric complaints in the form of a decrease in hearing threshold to permanent deafness 15,11,10,16. Based on applicable regulations in Indonesia, the threshold value used for the noise level in the work environment for 8 hours per day is $85 \mathrm{dBA}$ so that fishermen who are exposed to noise that exceeds the threshold value will result in a decrease in the hearing threshold 4,38. The length of exposure and the period of exposure to noise will exacerbate the degree of hearing loss experienced by fishermen 17. Fishermen who are exposed to noise for a long duration have a higher risk of experiencing a decrease in hearing threshold to deafness 39 .

Non-compliance with the use of ear protection while on a boat that makes noise is a risk factor for the occurrence of hearing loss in fishermen. This is in line with the results of the study, namely $65.2 \%$ of the 186 fishermen who did not use ear protection equipment in the form of earplugs had hearing loss due to noise exposure as evidenced by statistical analysis $p$ value $=0.046(p<0.05)$ 15. Ear protection equipment in the form of earplugs is proven to reduce the noise exposure received by fishermen by 30 to 40 $\mathrm{dBA} 40$. The frequency and depth of diving performed by traditional diving fishermen will also affect the occurrence of ear barotrauma which can cause hearing loss 18,19,20. This is in accordance with research on the description of hearing loss in diving activities, namely the longer and the deeper the dive, the greater the risk of hearing loss 41 .

\section{CONCLUSIONS}

Fishermen are at risk of experiencing work-related hearing loss due to exposure to noise from boat engines and improper diving techniques. There are two risk factors that can cause hearing loss in fishermen, namely personal factors such as age, years of service, knowledge, attitudes and
Journal of Drug Delivery \& Therapeutics. 2021; 11(3):153-59

behavior of fishermen, while other risk factors are occupational factors in the form of noise intensity from boat engines and compressor engines, long exposure to noise, availability of ear protection equipment, length of time and depth of diving performed by fishermen.

\section{ACKNOWLEDGMENTS}

The author would like to thank all parties involved in making this article, especially to all the lecturers at the Faculty of Public Health at Airlangga University. The author hopes that this article can add information to readers and provide benefits for the development of science in the field of occupational safety and health.

\section{CONFLICTS OF INTEREST}

The author states that there is no conflict of interest for this article.

\section{REFERENCES}

1. Direktorat Pengelolaan Ruang Laut. Konservasi Perairan Sebagai Upaya Menjaga Potensi Kelautan Dan Perikanan Indonesia. Jakarta; 2020.

2. Badan Pusat Statistik. Jumlah Rumah Tangga Perikanan Tangkap Menurut Provinsi Dan Jenis Penangkapan Tahun 20002016.; 2019.

3. Kementerian Kelautan dan Perikanan. Jumlah Nelayan Di Indonesia. Jakarta; 2019

4. International Labour Organizational. Keselamatan Dan Kesehatan Kerja Sarana Untuk Produktivitas. Jakarta: International Labour Office; 2013.

5. Mandal S, Hasan I, Hawlader NH, Sultana I, Rahman M, Majumder SI. Occupational Health Hazard and Safety Assessment of Fishermen Community in Coastal Zone of Bangladesh. Int J Heal Econ Policy. 2017; 2(2):63-71. doi:10.11648/j.hep.20170202.14

6. Halajur U. Promosi Kesehatan Di Tempat Kerja. Malang: Wineka Media; 2019.

7. Djatmiko RD. Kesehatan Dan Keselamatan Kerja. Yogyakarta: CV Budi Utama; 2016.

8. Levin JL, Curry WF, Shepherd S, Nalbone JT, Nonnenmann MW. Hearing loss and noise exposure among commercial fishermen in the gulf coast. J Occup Environ Med. 2016; 58(3):306-313.

9. The National Institute for Occupational Safety and Health. Occupational Hearing Loss Surveillance. Washington D.C; 2019.

10. Anwar M, Savitri E, Dyah T. Audiometric Profile of Fishermen using Motor Boat in Barombong Village, Makassar. Indian J Public Heal Res Dev. 2019; 10(10):1530-1534. doi:10.5958/0976-5506.2019.03055.9

11. Tasik YI. Analisis Hubungan Tingkat Kebisingan terhadap Penurunan Ambang Dengar (Hearing Loss) pada Nelayan Kelurahan Pontap Kota Palopo Provinsi Sulawesi Selatan Tahun 2016. J Kesehat Mega Buana. 2018; 4(1):1-9.

12. Pinto EA, Indriastuti D, Mien, Tahiruddin, Narmawan. Hubungan Pengetahuan dan Sikap dengan Kejadian Barotrauma pada Penyelam Suku Kadatua Tanpa Scuba. WINS J. 2020; 1(1):7-12.

13. Rahman Z, Kurniawati D, Apriani R. Hubungan Pengetahuan dengan Gangguan Pendengaran Akibat Penyemanan Pada Penyelam Tradisional di Kampus Bugis: Case Report. J Ilm Keperawatan Stikes Hang Tuah Surabaya. 2020; 15(2):172-185.

14. Kusnanto K, Wabula LR, Purwanto B, Arifin H, Kurniawati Y. Safety Behaviour and Healthy Diving: A Qualitative Study in the Traditional Diverse Fishermen. Int Marit Health. 2020; 71(1):56-61. doi:10.5603/IMH.2020.0012

15. Sholihah Q, Hanafi AS. Relationship of Noise and the Use of Ear Plugs with Hearing Disorders on Fishermen. Asian J Sci Res. 2017; 10(2):104-109. doi:10.3923/ajsr.2017.104.109

16. Vinezzia D. Identifikasi Bahaya Keselamatan dan Kesehatan Kerja pada Aktivitas Nelayan. J Penelit Perawat Prof. 2021;3(1):117-126.

17. Navisah SF, Ma'rufi I, Sujoso ADP. Faktor Risiko Barotrauma Telinga pada Nelayan Penyelam di Dusun Watu Ulo Desa Sumberejo Kecamatan Ambulu Kabupaten Jember. J IKESMA. 2016; 12(1):98-112.

18. Fatimah, Andarini S, Astari AM. Diving Frequency Increase the Risk Barotrauma in Traditional Fisherman-Divers. J Kedokt 
Brawijaya. 2019; 30(4):283-286.

19. Martinus I, Hadisaputro S, Munasik M. Berbagai Faktor yang Berpengaruh terhadap Barotrauma Telinga Tengah pada Penyelam Tradisional (Studi di Wilayah Balaesang Tanjung Kabupaten Donggala). J Epidemiol Kesehat Komunitas. 2019; 4(2):55-63.

20. Arini D, Setiadi, Sustrami D, Budiarti A, Astuti NM. Safety Factors Affecting The Health Status of Traditional Fisherman in The Coastal Area Surabaya. Stikes Hang Tuah Surabaya J. 2020; 1(1):1-8.

21. Sangaji M, Sillehu S, Umasugi MT, et al. Factors Related to Hearing Disorder on Traditional Fishermen in Namrole SubDistrict South Buru Regency. Indian J Forensic Med Toxicol. 2020; 14(2):2603-2608. doi:10.37506/ijfmt.v14i2.3511

22. Mesquita E, Isaac-Nahum V. Traditional Knowledge and Artisanal Fishing Technology on the Xingu River in Pará, Brazil. Brazilian J Biol. 2015; 75(3 suppl 1):138-157. doi:10.1590/1519-6984.01314bm

23. Mansi F, Cannone ESS, Caputi A, et al. Occupational Exposure on Board Fishing Vessels: Risk Assessments of Biomechanical Overload, Noise and Vibrations among Worker on Fishing Vessels in Southern Italy. MDPI J. 2019; 6(12):1-14. doi:10.3390/environments6120127

24. Besen E, Young AE, Gaines B, Pransky G. Relationship Between Age, Tenure, and Disability Duration in Persons with Compensated Work-Related Conditions. J Occup Environ Med. 2016; 58(2):140-147.

25. Istiqomah $\mathrm{SN}$, Imanto $\mathrm{M}$. Kualitas Hidup Lansia dengan Gangguan Pendengaran. Med J Lampung Univ. 2019; 8(2):234239.

26. Septiana NR, Widowati E. Gangguan Pendengaran akibat Bising. HIGEIA Oournal Public Heal Res Dev. 2017;1(1):73-82. http://journal.unnes.ac.id/sju/index.php/higeia.

27. Kurniawan W, Setyaningsih Y, Wahyuni I. Hubungan Faktor Karakteristik Pekerja, Safety Morning Talk (SMT) dan Housekeeping dengan Kejadian Minor Injury pada Pekerja di Proyek Pembangunan Gedung Kantor PT. X Jakarta. J Kesehat Masy. 2017; 5(3):323-331.

28. Fitriani ZA. Gangguan Pendengaran Akibat Bising dan FaktorFaktor yang Berhubungan pada Pekerja Perusahaan X (Evaluasi Suatu Program Konservasi Pendengaran). Maj Kesehat Pharmamedika. 2019; 11(1):50-57.

29. Sundstrup E, Hansen ÅM, Mortensen EL, et al. Cumulative Occupational Mechanical Exposures during Working Life and Risk of Sickness Absence and Disability Pension: Prospective
Journal of Drug Delivery \& Therapeutics. 2021; 11(3):153-59

Cohort Study. Scand J Work Environ Heal. 2017; 43(5):415-425.

30. Kusumadewi IP, Suwondo A, Jayanti S. Faktor Risiko yang Berhubungan dengan Kejadian Peningkatan Nilai Ambang Dengar pada Pekerja di Bagian Produksi Body Mini Bus PT X Magelang. J Kesehat Masy. 2018; 6(6):548-555.

31. Rudyarti E. Hubungan Pengetahuan Keselamatan dan Kesehatan Kerja dan Sikap Penggunaan Alat Pelindung Diri dengan Kejadian Kecelakaan Kerja pada Pengrajin Pisau Batik di PT. X. J Ind Hyg Occup Heal. 2017; 2(1):31-43.

32. Koesdianasari ES. Gangguan Pendengaran Pada Pekerja Bawah Air di Perusahaan Konstruksi Bawah Laut. Indones J Occup Saf Heal. 2018; 7(3):348-356. doi:10.20473/ijosh.v7i3.2018.348

33. ONeill OJ, Brett K, Frank AJ. Middle Ear Barotrauma. Florida: StatPearls Publishing, LLC; 2020.

34. Livingstone D, Smith K, Lange B. Scuba Diving and Otology: A Systematic Review with Recommendations on Diagnosis, Treatment and Post-operative Care. Diving Hyperb Med J. 2017; 47(2):97-109.

35. Kalalo SY, Kaunang WPJ, Kawatu PAT. Hubungan antara Pengetahuan dan Sikap Tentang K3 dengan Kejadian Kecelakaan Kerja pada Kelompok Nelayan di Desa Belang Kecamatan Belang Kabupaten Minahasa Tenggara. Pharmacon J Ilm Farm. 2016; 5(1):244-251.

36. Astuti IM, Nurtjahjanti H. Hubungan antara Sikap terhadap Keselamatan Kerja dengan Komitmen Organisasi pada Pegawai PT. PLN (Persero) Area Pelaksana Pemeliharaan Semarang. J Empati. 2018; 6(4):439-443.

37. Bird FE, Germain GE, Clark MD. Practical Loss Control Leadership. Third Edit. USA: Det Norske Veritas; 2003.

38. Li Y, Wu X, Luo X, Gao J, Yin W. Impact of Safety Attitude on The Safety Behavior of Coal Miners in China. MDPI J. 2019; 11(22):121.

39. Hamid M. The Analysis of Hearing Threshold Level of Noise Exposed Workers in Circulator Loom Unit. Indones J Occup Saf Heal. 2020; 9(2):214-221.

40. Li X, Dong Q, Wang B, Song H, Wang S, Zhu B. The Influence of Occupational Noise Exposure on Cardiovascular and Hearing Conditions among Industrial Workers. Sci Rep. 2019; 9(1):1-7.

41. Wardani RWK, Nurika G, Lutfiya I, Nawawinetu ED. Noise and Subjective Complaints of Workers As Effort to Control The Occurrence of Noise Induced Permanent Threshold Shift (NIPTS). J Vocat Heal Stud. 2020; 03(1):89-96.

42. Walangitan AC, Palandeng OI, Runtuwene J. Gambaran Gangguan Pendengaran pada Penyelam. J Biomedik. 2021; 13(2):192-198. 